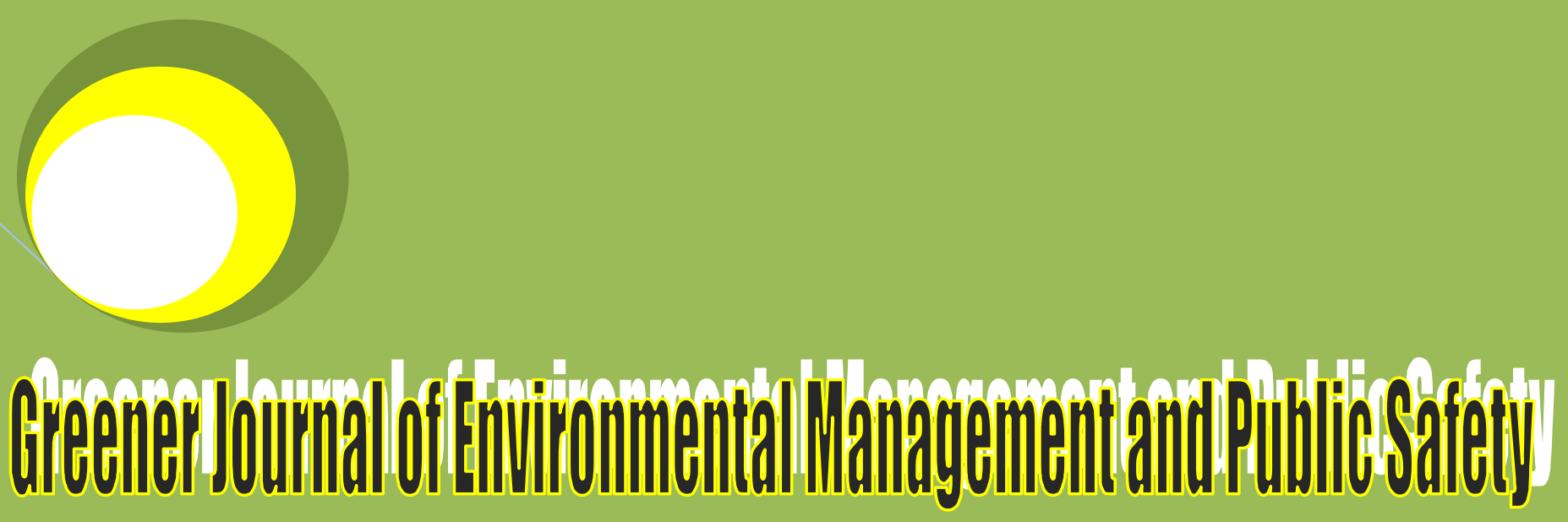

ISSN: 2354-2276

Submitted: $21 / 12 / 2016$

Accepted: 23/12/2016

Published: 27/12/2016

DOI: http://doi.org/10.15580/GJEMPS.2016.5.122116219

Spatial and Seasonal

Variation in Physico-

chemical Quality of

Ikoli Creek, Niger

Delta, Nigeria

By

Seiyaboh EI

Alagha WE

Gijo AH 


\title{
Spatial and Seasonal Variation in Physico-chemical Quality of Ikoli Creek, Niger Delta, Nigeria
}

\section{${ }^{1 *}$ Seiyaboh El, ${ }^{2}$ Alagha WE and ${ }^{1}$ Gijo AH}

\author{
${ }^{1}$ Department of Biological Science, Faculty of Science, Niger Delta University, Wilberforce Island, Bayelsa State, \\ Nigeria \\ ${ }^{2}$ School of Applied Sciences, Federal Polytechnic of Oil \& Gas Ekowe, Bayelsa State, Nigeria
}

${ }^{*}$ Corresponding Author’s E-mail: seiyabohenetimi@gmail.com

\begin{abstract}
This study assessed the Spatial and seasonal variation in Physico-chemical quality of Ikoli creek, Niger Delta, Nigeria. Triplicate samples were obtained from 5 locations for a two seasons viz; March and June, 2014. The water samples were analyzed following standard methods. Mean seasonality results for dry and wet were 27.47 and $27.33^{\circ} \mathrm{C}$ (temperature), 6.78 and $7.102(\mathrm{pH}), 27.766$ and $42.738 \mu \mathrm{S} / \mathrm{cm}$ (conductivity), 45.492 and $29.354 \mathrm{NTU}$ (turbidity), 7.298 and $23.868 \mathrm{mg} / \mathrm{l}$ (total dissolved solid), 24.45 and $10.712 \mathrm{mg} / \mathrm{l}$ (biological oxygen demand), 5.734 and 7.558 (dissolved oxygen), 0.066 and $0.072 \mathrm{mg} / \mathrm{l}$ (nitrite), 0.114 and $0.112 \mathrm{mg} / \mathrm{l}$ (nitrate), 3.14 and $3.088 \mathrm{mg} / \mathrm{l}$ (chloride), 4.354 and $4.336 \mathrm{mg} / \mathrm{l}$ (sulphate), 2.234 and $2.634 \mathrm{mg} / \mathrm{l}$ (calcium), 1.888 and $2.576 \mathrm{mg} / \mathrm{l}$ (potassium), 3.638 and $4.066 \mathrm{mg} / \mathrm{l}$ (sodium) and 1.348 and $1.732 \mathrm{mg} / \mathrm{l}$ (magnesium) respectively. There was significance difference $(P<0.05)$ in most parameters for spatial distribution as well as seasonality. The study showed that season affect physico-chemical quality of Ikoli creek. Anthropogenic activities in the creek could affect the physico-chemical quality of water. This could be the reason while there was variation based on spatial distribution
\end{abstract}

Keywords: Bayelsa state, Ikoli Creek, Water quality

\section{INTRODUCTION}

Several surface water found in the Niger Delta region of Nigeria including rivers, ponds, lakes, streams, creeks, creeklets (Agedah et al., 2015; Izah and Ineyougha, 2015; Izah and Srivastav, 2015; Izah et al., 2016; Ogamba et al., 2015a). Different categories of wastes stream (solid, effluents, sewage) are deposited in most surface water in coastal communities in the Niger Delta especially Bayelsa state (Ogamba et al., 2015a). Most of this wastes are generated in various section including hospital, market, house hold (Angaye et al., 2015). Some are discarded close to surface water which is washed into the surface water after rainfall via runoff. Other material that could be discharged into the surface water when they are indiscriminately applied in agricultural field or home close to surface water is pesticides (herbicides, insecticides, fungicides, rodenticides etc) (Inyang et al., 2016a-c). Food processing wastes such as oil palm processing (Izah et al., 2016b), cassava processing could contaminate surface water. These activities on the surface water could affect the water quality including microbial density and diversity, heavy metals, oxygen related parameter and general physicochemical properties (Ogamba et al., 2015a,b,c; Izah and Ineyougha, 2015).

Bayelsa state lies in the sedimentary basin and fishing is a major source of livelihood to several families (Ohimain et al., 2009), especially the once aligning the coastal communities. Furthermore, several economic activities are carried out in the water ways including navigation and water transportation of humans and other agricultural produce, timber for construction works etc. The activities in the water could have impact on water quality as well. This is because most wastes discharge into surface water (directly or indirectly) contains high solid materials (including suspended and dissolved solid), organics and oil and grease.

The usefulness of water to biodiversity including plants, animals, microbes, human is enormous. Water is a major part of most biological resources. Water is also a home to several life forms including fisheries, aquatic mammals and reptiles, aquatic plants (macrophytes), plankton (phytoplankton and zooplankton), benthic organisms (Izah and Srivastav, 2015). Several types of water bodies including estuarine, marine and freshwater are found in 
large volumes and the organisms that thrive in each type is differs depending on their adaption strategies/mechanisms.

Like groundwater and rainwater, fresh surface water is a source of potable water to several families in Nigeria especially in rural area or communities that groundwater is not readily available (Izah et al., 2015, 2016a; Izah and Ineyougha, 2015; Izah and Izah and Srivastav, 2015). Surface water is also used for domestic activities like cooking, washing bathing etc.

Several studies have been carried out in groundwater resources in Bayelsa state including Yenagoa metropolis (Nkamare et al., 2012; Ohimain et al., 2013; Agbalagba et al., 2011; Amangabara and Ejenma, 2012; Oborie and Nwankwoala, 2014; Nwankwoala et al., 2014 ; Okiongbo and Douglas, 2013), surface water including river nun (Agedah et al., 2015; Ogamba et al., 2015b), Kolo creek (Ogamba et al., 2015c), Igbedi creek (Seiyabog et al., 2013), Taylor creek and Nun River (Daka et al., 2014), Sagbama creek (Seiyaboh et al., 2017), Epie creek (Izonfuo and Benwari, 2001).

However, information about lkoli creek around abattoir area has been previously reported by Ogamba et al. (2015a). As such, this present study focus on spatial and seasonal variation in Physico-chemical quality of the creek. The physicochemical quality of the creek water was compared with Nigeria drinking water quality standard, 2007.

\section{MATERIALS AND METHODS}

\subsection{Study Area}

The Niger Delta has several creeks, a tributary of major rivers. In Bayelsa state for instance, several creek emanated from Nun river. Ikoli creek is one of the tributaries of Nun River that passes through Yenagoa, the Bayelsa state capital. The economic activities and climatic condition of the area have been previously described by Seiyaboh et al. (2016), Ogamba et al. (2015a), Ogamba et al. (2016).

\subsection{Sampling Stations and Collection}

Triplicate water samples were collected as subsurface (15-20cm depth) from five locations in March (dry season) and June (wet season) 2014. I litre containers was used for sample collection. The samples were labeled accordingly and transported to the laboratory for analysis.

\subsection{Physicochemical and heavy metal analysis}

The water quality parameters were analyzed in-situ viz: $\mathrm{PH}$, conductivity, temperature, turbidity, total dissolved solid, dissolved oxygen using probes and ex-situ including biological oxygen demand, nitrite, nitrate, chloride, sulphate, calcium, potassium, magnesium, sodium using the method previously described by APHA (1975), Ademoroti (1996).

\subsection{Statistical Analysis}

SPSS was used to carry out the statistical analysis. Data were expressed as mean. One way analysis of variance was used to show significance difference $(P=0.05)$ for spatial distribution. Duncan statistics was used for mean separation; and t-test was used for seasonal variation at $\mathrm{P}=0.05$.

\subsection{RESULTS AND DISCUSSION}

Table 1 and 2 presents spatial and seasonal variation in physicochemical characteristics of water samples from Ikoli creek. Temperature ranged from $27.08-27.52^{\circ} \mathrm{C}$ being not significantly different $(P>0.05)$ among the different location apart from location C. Based on seasons, mean temperature for dry and wet seasons were 27.47 and 27.33 ${ }^{\circ} \mathrm{C}$, being not significantly different $(P>0.05)$. Lack of variation is season suggest that water temperature of the area is not significantly affect by season. However, slight variation in spatial distribution could be associated to sampling period (Agedah et al., 2015). The findings of this study had some similarity with the work of Agedah et al. (2015) from some rivers around Wilberforce Island; Ogamba et al. (2015a) from Ikoli creek around abattoirs; Izonfuo and Bariweni (2001) from Epie creek. But higher than the values previously reported by Aghoghovwia and Ohimain (2014) from lower Kolo creek. The variation in temperature could be associated in sampling period. However, the values are within ambient temperature of the area. 
The spatial distribution for $\mathrm{pH}$ of the water ranged from $6.97-7.01$, being not significantly different $(P>0.05)$ among the various location (Table 1). Furthermore, seasonal variation showed significant variation $(P<0.05)$ between both seasons with mean value of 6.78 (dry season) and 7.10 (wet season). The variation in seasons could be due to

dilution factor in wet season of the creek. The $\mathrm{pH}$ of the water had some similarity with previous works in surface water including Epie creek (Izonfuo and Bariwari, 2001), Kolo creek (Ogamba et al., 2015c; Aghoghovwia and Ohimain, 2014), Igbedi creek (Seiyaboh et al., 2013), Ikoli creek close to abattoir (Ogamba et al., 2015a), Nun river and Taylor creek (Daka et al., 2014). The $\mathrm{pH}$ of the water is within the range of $6.5-8.5$ for drinking water as specified by Standard Organization of Nigeria (SON, 2007; Agedah et al., 2015).

The conductivity of the water samples ranged from $35.70-39.06 \mu \mathrm{S} / \mathrm{cm}$ (for spatial distribution) and mean value of $27.77 \mu \mathrm{S} / \mathrm{cm}$ (dry season) and $42.74 \mu \mathrm{S} / \mathrm{cm}$ (wet season). Basically there was significance difference $(\mathrm{P}<0.05)$ in location and seasons. Variation in conductivity could be due to difference in anthropogenic activities in the water at various location and seasons. The conductivity level observed in this study is lesser than the values previously reported in some surface water in Bayelsa including lower Kolo creek (Aghoghovwia and Ohimain, 2014; Ogamba et al., 2015c), Igbedi creek (Seiyaboh et al., 2013), Ikoli creek close to abattoir (Ogamba et al., 2015a), Efi lake (Angaye and Mieyepa, 2015), Nun river and Taylor creek (Daka et al., 2014). The conductivity surface water in the Bayelsa state is within the maximum permissible limit of $1000 \mu \mathrm{S} / \mathrm{cm}$ for potable water sources.

Turbidity of the water samples ranged from $32.20-39.06$ NTU (for spatial distribution) and mean value of 45.49NTU (dry season) and 29.35 NTU (wet season) for seasonal variation. Typically, there was significance variation $(P<0.05)$ in location and seasons. Differences could be due to effect or runoff after rain fall in wet season, wastes discharged into the water, different anthropogenic activities in the creek and natural characteristics of the creek. Turbidity level is comparable to the values previously reported in surface water in Nigeria including Epie creek (Izonfuo and Bariweni, 2001), Kolo creek (Aghoghovwia and Ohimain, 2014), Nun river (Ogamba et al., 2015b), Ikoli creek close to area abattoir wastes are discharged into (Ogamba et al., 2015a), but higher than values reported in some surface water including Igbedi creek (Seiyaboh et al., 2013). Variation in turbidity level of the creek depends on seasons and prevailing anthropogenic activities in the area. The turbidity has exceeded maximum allowable value of 5NTU in drinking water as specified by SON (2007).

Total dissolved solid of the water samples ranged from $14.58-17.05 \mathrm{mg} / \mathrm{l}$ for spatial distribution and mean value of $7.29 \mathrm{mg} / \mathrm{l}$ (dry season) and $10.712 \mathrm{mg} / \mathrm{l}$ (wet season). There was significance variation $(\mathrm{P}<0.05)$ in location and seasons. Higher total dissolved solid during the wet season could be due to movement of materials found in the water. Again, overflows and dilution effects increases during wet season this could also be a reason while total dissolved solid is higher dry season (Agedah et al., 2015). The concentration reported in this study is lower than previous reported from surface water in Bayelsa state including Epie creek (Izonfuo and Bariwani, 2001), Igbedi creek (Seiyaboh et al., 2013), Kolo creek (Ogamba et al., 2015c; Aghoghovwia and Ohimain, 2014), Nun River and Taylor creek (Daka et al., 2014), some rivers around Wilberforce Island (Agedah et al., 2015), Ikoli creek close to area abattoir wastes are discharged into (Ogamba et al., 2015a). But comparable to the value reported in Nun River by Ogamba et al. (2015b). The total dissolved solid is lower than $500 \mathrm{mg} / \mathrm{l}$ recommended for potable water in Nigeria (SON, 2007). The differences could be due to the period of the study and prevailing anthropogenic activities.

Table 1: Spatial variation in Physico-chemical quality of Ikoli creek

\begin{tabular}{|l|l|l|l|l|l|}
\hline \multirow{2}{*}{ Parameters } & \multicolumn{5}{|c|}{ Locations } \\
\cline { 2 - 6 } & $\mathrm{A}$ & $\mathrm{B}$ & $\mathrm{C}$ & $\mathrm{D}$ & $\mathrm{E}$ \\
\hline Temp. $\left({ }^{\circ} \mathrm{C}\right)$ & $27.52^{\mathrm{b}}$ & $27.42^{\mathrm{b}}$ & $27.08^{\mathrm{a}}$ & $27.36^{\mathrm{b}}$ & $27.36^{\mathrm{b}}$ \\
\hline pH & $6.99^{\mathrm{a}}$ & $7.01^{\mathrm{a}}$ & $7.01^{\mathrm{a}}$ & $6.99^{\mathrm{a}}$ & $6.97^{\mathrm{a}}$ \\
\hline Conductivity $(\mu \mathrm{S} / \mathrm{cm})$ & $35.70^{\mathrm{a}}$ & $37.08^{\mathrm{c}}$ & $36.90^{\mathrm{bc}}$ & $36.28^{\mathrm{ab}}$ & $39.23^{\mathrm{d}}$ \\
\hline Turbidity $(\mathrm{NTU})$ & $38.70^{\mathrm{c}}$ & $37.57^{\mathrm{c}}$ & $33.97^{\mathrm{b}}$ & $32.20^{\mathrm{a}}$ & $39.06^{\mathrm{c}}$ \\
\hline TDS $(\mathrm{mg} / \mathrm{l})$ & $17.05^{\mathrm{c}}$ & $15.12^{\mathrm{ab}}$ & $14.83^{\mathrm{a}}$ & $14.58^{\mathrm{a}}$ & $16.23^{\mathrm{bc}}$ \\
\hline DO $(\mathrm{mg} / \mathrm{l})$ & $8.12^{\mathrm{e}}$ & $7.08^{\mathrm{d}}$ & $6.40^{\mathrm{b}}$ & $5.99^{\mathrm{a}}$ & $6.6^{\mathrm{c}}$ \\
\hline BOD $(\mathrm{mg} / \mathrm{l})$ & $15.99^{\mathrm{c}}$ & $16.83^{\mathrm{c}}$ & $14.11^{\mathrm{ab}}$ & $12.36^{\mathrm{a}}$ & $15.91^{\mathrm{bc}}$ \\
\hline Nitrite $(\mathrm{mg} / \mathrm{l})$ & $0.09^{\mathrm{b}}$ & $0.07^{\mathrm{c}}$ & $0.05^{\mathrm{a}}$ & $0.05^{\mathrm{a}}$ & $0.10^{\mathrm{d}}$ \\
\hline Nitrate $(\mathrm{mg} / \mathrm{l})$ & $0.11^{\mathrm{a}}$ & $0.13^{\mathrm{a}}$ & $0.11^{\mathrm{a}}$ & $0.11^{\mathrm{a}}$ & $0.11^{\mathrm{a}}$ \\
\hline Chloride $(\mathrm{mg} / \mathrm{l})$ & $3.42^{\mathrm{ab}}$ & $3.73^{\mathrm{b}}$ & $3.43^{\mathrm{ab}}$ & $2.73^{\mathrm{a}}$ & $2.88^{\mathrm{a}}$ \\
\hline Sulphate $(\mathrm{mg} / \mathrm{l})$ & $2.85^{\mathrm{a}}$ & $4.26^{\mathrm{b}}$ & $4.81^{\mathrm{bc}}$ & $5.23^{\mathrm{c}}$ & $4.25^{\mathrm{b}}$ \\
\hline Sodium $(\mathrm{mg} / \mathrm{l})$ & $2.84^{\mathrm{a}}$ & $4.40^{\mathrm{c}}$ & $4.22^{\mathrm{c}}$ & $4.22^{\mathrm{c}}$ & $3.58^{\mathrm{b}}$ \\
\hline Potassium $(\mathrm{mg} / \mathrm{l})$ & $2.01^{\mathrm{a}}$ & $2.34^{\mathrm{ab}}$ & $2.41^{\mathrm{b}}$ & $2.35^{\mathrm{ab}}$ & $2.05^{\mathrm{ab}}$ \\
\hline Calcium $(\mathrm{mg} / \mathrm{l})$ & $2.37^{\mathrm{a}}$ & $2.37^{\mathrm{a}}$ & $2.52^{\mathrm{a}}$ & $2.52^{\mathrm{a}}$ & $2.39^{\mathrm{a}}$ \\
\hline Magnesium $(\mathrm{mg} / \mathrm{l})$ & $1.16^{\mathrm{a}}$ & $1.46^{\mathrm{b}}$ & $1.88^{\mathrm{d}}$ & $1.66^{\mathrm{c}}$ & $1.31^{\mathrm{ab}}$ \\
\hline
\end{tabular}


Different letters as superscript across the row indicate significantly different $(P<0.05)$ according to Duncan statistics

Table 2: Seasonal variation physico-chemical characteristics of Ikoli creek, Niger Delta

\begin{tabular}{|c|c|c|c|c|c|c|c|}
\hline \multirow[t]{2}{*}{ Parameters } & \multicolumn{2}{|c|}{ Dry season } & \multicolumn{2}{|c|}{ Wet season } & \multirow[t]{2}{*}{ t-value } & \multirow{2}{*}{$\begin{array}{l}\mathrm{p}- \\
\text { value }\end{array}$} & \multirow{2}{*}{$\begin{array}{l}\text { Statistical } \\
\text { implications }\end{array}$} \\
\hline & Mean & Range & Mean & Range & & & \\
\hline Temp. $\left({ }^{\circ} \mathrm{C}\right)$ & 27.474 & $27.30-27.80$ & 27.334 & $26.89-27.53$ & 0.928 & 0.380 & NSD \\
\hline $\mathrm{Ph}$ & 6.78 & $6.72-6.86$ & 7.102 & $6.72-7.27$ & -3.085 & 0.015 & SD \\
\hline $\begin{array}{l}\text { Conductivity } \\
\text { ( } \mathrm{SS} / \mathrm{cm})\end{array}$ & 27.766 & $25.87-28.57$ & 42.738 & $27.93-49.90$ & -3.895 & 0.005 & SD \\
\hline Turbidity (NTU) & 45.492 & 37.73- 50.42 & 29.354 & $26.67-37.73$ & 4.975 & 0.001 & SD \\
\hline TDS (mg/l) & 7.298 & $6.83-7.40$ & 23.868 & $23.10-25.67$ & -23.754 & 0.000 & SD \\
\hline $\mathrm{BOD}(\mathrm{mg} / \mathrm{l})$ & 24.45 & $21.53-26.37$ & 10.712 & $6.80-25.01$ & 3.747 & 0.006 & SD \\
\hline $\mathrm{DO}(\mathrm{mg} / \mathrm{l})$ & 5.734 & $5.31-6.63$ & 7.558 & $5.45-9.60$ & -2.36 & 0.046 & SD \\
\hline Nitrite $(\mathrm{mg} / \mathrm{l})$ & 0.066 & $0.01-0.09$ & 0.072 & $0.02-0.10$ & -0.3 & 0.772 & NSD \\
\hline Nitrate $(\mathrm{mg} / \mathrm{l})$ & 0.114 & $0.09-0.13$ & 0.112 & $0.09-0.14$ & 0.183 & 0.86 & NSD \\
\hline Chloride $(\mathrm{mg} / \mathrm{l})$ & 3.14 & $2.60-4.10$ & 3.088 & $2.60-3.56$ & 0.163 & 0.874 & NSD \\
\hline Sulphate $(\mathrm{mg} / \mathrm{l})$ & 4.354 & $2.65-5.43$ & 4.336 & $3.04-5.59$ & 0.027 & 0.979 & NSD \\
\hline Sodium (mg/l) & 3.638 & $2.57-4.20$ & 4.066 & $3.11-4.60$ & -1.027 & 0.335 & NSD \\
\hline Potassium (mg/l) & 1.888 & $1.68-2.22$ & 2.576 & $2.38-2.67$ & -4.836 & 0.001 & SD \\
\hline Calcium (mg/l) & 2.234 & $2.11-2.53$ & 2.634 & $2.51-2.59$ & -3.761 & 0.006 & SD \\
\hline Magnesium (mg/l) & 1.348 & $1.10-1.67$ & 1.732 & $1.38-2.08$ & -2.362 & 0.046 & SD \\
\hline
\end{tabular}

NSD- Not Significantly different, SD = Significantly different

Biological oxygen demand and dissolve oxygen concentration ranged from $12.36-16.83 \mathrm{mg} / \mathrm{l}$ and $5.99-8.12 \mathrm{mg} / \mathrm{l}$ respectively for spatial distribution, and mean of 24.45 and $5.73 \mathrm{mg} / \mathrm{l}$ respectively (dry season) and 10.71 and $7.56 \mathrm{mg} / \mathrm{l}$ respectively (wet season). Basically there was significance variation $(P<0.05)$ in location and seasons for both parameter. The concentration observed in this study for dissolved oxygen is slightly lower than the concentration reported by Agedah et al. (2015) from surface water around Wilberforce Island. Dissolved oxygen is close to the work of Daka et al. (2014) from Nun River and Taylor creek. The concentration of dissolved oxygen is comparable, while biological oxygen demand has higher than the level previously reported in Kolo creek by Aghoghovwia and Ohimain (2014). But higher than the concentration reported by Seiyaboh et al. (2013) from Igbedi creek; Izonfuo and Benwari (2001) from Epie creek for both dissolved oxygen and biological oxygen demand. The variation could be due differences in the characteristics of the various water bodies and prevailing condition close to the area. Also different in sampling period could also contribute to variation in dissolved oxygen of the water. This is because dissolved oxygen of water is usually in order: morning or night > afternoon (Ezekiel et al., 2011).

The anions concentration of the water including nitrite, nitrate, chloride, sulphate ranged from $0.05-$ $0.10 \mathrm{mg} / \mathrm{l}, 0.11-0.13 \mathrm{mg} / \mathrm{l}, 2.73-3.73 \mathrm{mg} / \mathrm{l}$ and $2.85-5.23 \mathrm{mg} / \mathrm{l}$ respectively for spatial variation and mean of 0.07 , $0.11,3.14$ and $4.35 \mathrm{mg} / \mathrm{l}$ for dry season respectively and $0.07,0.11,3.09$ and $4.34 \mathrm{mg} / \mathrm{l}$ for wet season respectively. No significance variation $(P>0.05)$ between most of the location for all the parameters. However, there was no significance difference $(P>0.05)$ between different seasons. Lack of variation suggests that anion concentration in the water is not significantly affected by season. The concentration of anion observed in this study is far from the work of Seiyaboh et al. (2013) apart from nitrite. Daka et al. (2014) reported chloride and nitrate concentration not comparable to the findings of this study from Nun River and Taylor creek. Ogamba et al. (2015b) reported higher concentration of sulphate and chloride and lower level of nitrate in water samples from Nun River. Ogamba et al. (2015c) reported higher concentration of sulphate and chloride and comparable level of nitrate in water samples from Kolo creek. Chloride and nitrate concentration have similarity with the values previously reported in abattoir area of the creek as reported by Ogamba et al. (2015a). Izonfuo and Bariweni (2001) reported nitrate and chloride concentration in Epie creek which is comparable to the results of this study. The variation in this study from previous work could be associated to differences in characteristics of the water and its sediment. However, the anions concentration were within the maximum permissible limit of $50 \mathrm{mg} / \mathrm{l}$ (nitrate), $0.2 \mathrm{mg} / \mathrm{l}$ (nitrite), 100mg/l (sulphate) and 250mg/l (chloride) as specified by SON (2007).

The cation concentration of the water including sodium, potassium, calcium and magnesium ranged from $2.84-4.40 \mathrm{mg} / \mathrm{l}, 2.01-2.41 \mathrm{mg} / \mathrm{l}, 2.37-2.52 \mathrm{mg} / \mathrm{l}$ and $21.16-1.88 \mathrm{mg} / \mathrm{l}$ respectively for spatial variation and mean 
of $3.64,1.89,2,23$ and $1.35 \mathrm{mg} / \mathrm{l}$ for dry season respectively and $0.07,0.11,3.09$ and $4.34 \mathrm{mg} / \mathrm{l}$ for wet season respectively. Sodium concentration showed significant difference $(P<0.05)$ for spatial distribution and no significant variation $(P>0.05)$ among both seasons. Calcium and potassium showed no significance difference $(P>0.05)$ for

spatial distribution, but they are significantly different $(P<0.05)$ based on seasons. No significance variation $(P>0.05)$ between most of the location for all the parameters. However, there was no significance difference $(P>0.05)$ between various seasons. Like most anions, cations appear not to have been impacted by seasons. Difference in spatial distribution could be due to difference anthropogenic activities close to sampling locations. The concentration reported in this study for the various cations were higher than the values previously reported in Kolo creek (Ogamba et al. 2015c), Nun river (Ogamba et al., 2015b). Furthermore, Izonfuo and Bariweni (2011) reported higher calcium and magnesium and comparable sodium and potassium in Epie creek. Cation were within permissible limit 200mg/l (sodium), and higher than limit of $0.2 \mathrm{mg} / \mathrm{l}$ (magnesium) specified by SON (2007). Higher magnesium in water could result to poor acceptability by users.

\section{CONCLUSION}

Water is an essential resources need by living things including human. This study was designed to evaluate spatial and seasonal variation in Physico-chemical quality of water from Ikoli creek, Bayelsa state, Nigeria. The study found that there is significant variation $(\mathrm{P}<0.05)$ between both seasons with regard to $\mathrm{pH}$, conductivity, turbidity, total dissolved solid, dissolved oxygen, biological oxygen demand, potassium, calcium and magnesium concentration. Differences also exist based on locations. The water parameters were within the value recommended for potable water in Nigeria as specified by SON except turbidity and biological oxygen demand. As such we conclude that the water is unfit for drinking based on parameters assessed. Hence, there need to the treat the water prior to consumption and for other domestic purposes such as washing and cooking.

\section{REFERENCES}

Ademoroti, C.M.A. (1996). Standard Method for Water \& Effluents Analysis. $1^{\text {st }}$ Edition. Foludex press limited, Ibadan, Nigeria.

Agbalagba, O.E., Agbalagba O.H., Ononugbo, C. P. and Alao, A. A. (2011). Investigation into the physico-chemical properties and hydrochemical processes of groundwater from commercial boreholes In Yenagoa, Bayelsa State, Nigeria. African Journal of Environmental Science and Technology, 5(7): 473-481

Agedah, E.C., Ineyougha, E.R., Izah, S.C. and Orutugu, L.A. (2015). Enumeration of total heterotrophic bacteria and some physico-chemical characteristics of surface water used for drinking sources in Wilberforce Island, Nigeria. Journal of Environmental Treatment Techniques, 3(1):28 - 34.

Aghoghovwia, O. A. and Ohimain, E. I. (2014). Physicochemical characteristics of lower Kolo creek, Otuogidi, Bayelsa state. Nigerian Journal of Agriculture, Food and Environment, 10(1):23 - 26

Amangabara, G.T. and Ejenma, E. (2012). Groundwater Quality Assessment of Yenagoa and Environs Bayelsa State, Nigeria between 2010 and 2011. Resources and Environment, 2(2): 20-29.

American Public Health Association (APHA) (1975). Standard methods for the evaluation of water and waste waters. $20^{\text {th }}$ Ed. Wahington DC. American Public health.

Angaye T.C.N. and Mieyepa, C.E. (2015). Assessment of Elemental and Microbial Quality of Lake Efi In Bayelsa State, Central Niger Delta, Nigeria. Journal of Environmental Treatment Techniques, 3(2): 71 - 75.

Angaye, T.C.N., Zige, D.V. and Izah, S.C. (2015). Microbial load and heavy metals properties of leachates from solid wastes dumpsites in the Niger Delta, Nigeria. Journal of Environmental Treatment Techniques. 3(3): 175 - 180.

Daka, E.R., Amakiri-Whyte, B. and Inyang, I.R. (2014). Surface and Groundwater Quality in Some Oil Field Communities in the Niger Delta: Implications for Domestic Use and Building Construction. Research Journal of Environmental and Earth Sciences 6(2): 78-84.

Ezekiel, E.N., Hart A.I. and Abowei, J.F.N. (2011). The Physical and Chemical Condition of Sombreiro River, Niger Delta, Nigeria. Research Journal of Environmental and Earth Sciences, 3(4): 327-340.

Inyang, I.R., Okon, N.C. and Izah, S.C. (2016a). Effect of glyphosate on some enzymes and electrolytes in Heterobranchus bidosalis (a common African catfish). Biotechnological Research, 2(4):161-165.

Inyang, I.R., Thomas, S. and Izah, S.C. (2016b). Evaluation of Activities of Transferases and Phosphatase in Plasma and Organs of Clarias gariepinus Exposed to Fluazifop-p-Butyl. Journal of Environmental Treatment Techniques, 4(3): 94-97

Inyang, IR, Akio K and Izah SC (2016c). Effect of dimethoate on lactate dehydrogenase, creatinine kinase and amylase in Clarias lazera. Biotechnological Research, 2(4): 155- 160. 
Izah SC, Angaye TCN and Ohimain El. (2015). Estimation of potential chronic daily intake of heavy metal through consumption of potable water in South-south Nigeria. Bulletin of Advanced Scientific Research. 1(1):33 - 36.

Izah, S.C. and Ineyougha, E.R. (2015). A review of the microbial quality of potable water sources in Nigeria. Journal of Advances in Biological and Basic Research, 1(1): 12 - 19.

Izah, S.C. and Srivastav, A.L. (2015). Level of arsenic in potable water sources in Nigeria and their potential health impacts: A review. Journal of Environmental Treatment Techniques, 3(1): $15-24$.

Izah, S.C., Chakrabarty, N. and Srivastav, A.L. (2016a). A Review on Heavy Metal Concentration in Potable Water Sources in Nigeria: Human Health Effects and Mitigating Measures. Exposure and Health, 8:285-304.

Izah, S.C., Angaye, T.C.N. and Ohimain, E.I. (2016b). Environmental Impacts of Oil palm processing in Nigeria. Biotechnological Research, 2(3):132-141

Izonfuo, L.W.A. and Bariweni, A. P. (2001). The effect of urban runoff water and human activities on some physicochemical parameters of the Epie Creek in the Niger Delta. Journal of Applied Sciences and Environmental Management, 5(1):47-55.

Nkamare, M.B., Ofili, A.N. and Adeleke, A.J. (2012). Physico-chemical and microbiological assessment of borehole water in Okutukutu, Bayelsa State, Nigeria. Advances in Applied Science Research, 3(5): 2549-2552.

Nwankwoala, H.O., Amadi, A.N., Oborie, E. and Ushie, F.A. (2014). Hydrochemical Factors and Correlation Analysis in Groundwater Quality in Yenagoa, Bayelsa State, Nigeria. Applied Ecology and Environmental Sciences, 2(4), 100-105.

Oborie, E. and Nwankwoala, H.O. (2014). Analysis of Major Ion Constituents in Groundwater of Amassoma and Environs, Bayelsa State, Nigeria. Journal of Applied Chemistry, 2 (5):1-13.

Ogamba, E.N., Izah, S.C. and Toikumo, B.P. (2015a). Water quality and levels of lead and mercury in Eichhornia crassipes from a tidal creek receiving abattoir effluent, in the Niger Delta, Nigeria. Continental Journal of Environmental Science, 9(1): $13-25$.

Ogamba, E.N., Izah, S.C. and Oribu, T. (201b). Water quality and proximate analysis of Eichhornia crassipes from River Nun, Amassoma Axis, Nigeria. Research Journal of Phytomedicine, 1(1): $43-48$.

Ogamba, E.N., Seiyaboh, E.I., Izah, S.C., Ogbugo, I. and Demedongha, F.K. (2015c). Water quality, phytochemistry and proximate constituents of Eichhornia crassipes from Kolo creek, Niger Delta, Nigeria. International Journal of Applied Research and Technology, 4(9): $77-84$.

Ogamba, E.N., Izah, S.C. and Ofoni-Ofoni, A.S. (2016). Bioaccumulation of Chromium, Lead and Cadmium in the bones and tissues of Oreochromis niloticus and Clarias camerunensis from Ikoli creek, Niger Delta, Nigeria. Advanced Science Journal of Zoology, 1(1): $13-16$.

Ohimain, E.1. Angaye, T.N.C. and Okiongbo, K.S. (2013). Removal of iron, coliforms and acidity from ground water obtained from shallow aquifer using trickling filter method. Journal of Environmental Science and Engineering, A2: 349-355.

Ohimain, E.I., Bassey, S. and Bawo, D.D.S. (2009). Uses of seashells for civil construction works in coastal Bayelsa State, Nigeria: a waste management perspective. Research Journal of Biological Sciences, 4: 1025 - 1031.

Okiongbo, K.S. and Douglas, R. (2013). Hydrogeochemical analysis and evaluation of groundwater quality in Yenagoa city and environs, southern Nigeria. Ife Journal of Science, 15(2): $209-222$.

Seiyaboh, E.I., Inyang, I.R. and Izah, S.C. (2016). Seasonal Variation of Physico-Chemical Quality of Sediment from Ikoli Creek, Niger Delta. International Journal of Innovative Environmental Studies Research, 4(4): 29-34.

Seiyaboh, E.I., Izah, S.C. and Oweibi, S. (2017). Assessment of Water quality from Sagbama Creek, Niger Delta, Nigeria. Biotechnological Research, 3(1): in press.

Seiyaboh, E.I., Ogamba, E.N. and Utibe, D.I. (2013). Impact of Dredging on the Water Quality of Igbedi Creek, Upper Nun River, Niger Delta, Nigeria. IOSR Journal of Environmental Science, Toxicology and Food Technology, 7(5): $51-56$.

Standard organization of Nigeria (SON) (2007). Nigerian Standard for Drinking Water Quality. Nigerian industrial standard, Nigeria.

Cite this Article: Seiyaboh El, Alagha WE and Gijo AH (2016). Spatial and Seasonal Variation in Physico-chemical Quality of Ikoli Creek, Niger Delta, Nigeria. Greener Journal of Environmental Management and Public Safety, 5(5): 104-109, http://doi.org/10.15580/GJEMPS.2016.5.122116219 